\title{
優秀発表賞受賞論文
}

\section{Er:YAG レーザーを用いた根管洗浄時に生じる根尖孔外の圧力}

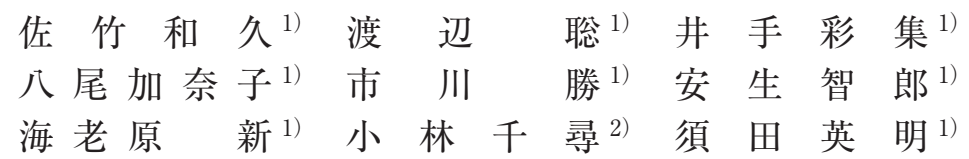

1) 東京医科歯科大学 (TMDU) 大学院医歯学総合研究科医歯学系専攻

口㬶機能再構築学講座歯髄生物学分野

2) 東京医科歯科大学歯学部附属病院歯科総合診療部

(受付： 2014 年 5 月 13 日, 受理 : 2014 年 7 月 2 日)

\section{Pressure Generated Outside the Apical Foramen During Er:YAG Laser-activated Irrigation}

\author{
Kazuhisa SATAKE ${ }^{1)}$, Satoshi WATANABE ${ }^{1)}$, Ayai IDE ${ }^{1)}$, \\ Kanako $\mathrm{YAO}^{1)}$, Masaru ICHIKAWA ${ }^{1)}$, Tomoo ANJO ${ }^{1)}$, \\ Arata EBIHARA ${ }^{1)}$, Chihiro KOBAYASHI ${ }^{2)}$ and Hideaki SUDA ${ }^{1)}$ \\ 1) Department of Pulp Biology and Endodontics, Division of Oral Health Sciences, Medical and Dental Sciences Track, \\ Graduate School of Medical and Dental Sciences, Tokyo Medical and Dental University (TMDU) \\ 2) Oral Diagnosis and General Dentistry, Dental Hospital, Tokyo Medical and Dental University (TMDU)
}

(Received: May 13, 2014, Accepted for Publication: July 2, 2014)

\begin{abstract}
Although root canal irrigation is an important process for successful root canal treatment, there is a high risk of irrigant extrusion into the periapical region. However, periapical pressure generated by laser-activated irrigation (LAI) using an Er:YAG laser has not been studied yet. The aim of this study was to investigate the root canal irrigation pressure generated outside the apical foramen during LAI using an Er:YAG laser in comparison with passive ultrasonic irrigation (PUI) and conventional irrigation $(\mathrm{CI})$.

A plastic root canal model shaped to a working length of $20 \mathrm{~mm}$ with an apical diameter of $0.40 \mathrm{~mm}$ was used. They were assigned into the following three groups:

1) LAI group: Distilled water was activated by Er:YAG laser (Erwin AdvErL, Morita, Japan, 70 mJ 10 pps) with a coneshaped tip (R200T, Morita, $\phi=200 \mu \mathrm{m}$ ) positioned $2 \mathrm{~mm}$ short of the working length for 20 seconds.

2) PUI group: PUI was performed for 20 seconds with an ultrasonic file, which was positioned 2 mm short of the canal end and driven by an ultrasonic device (Piezon Master 400, EMS, Switzerland, highest power setting).

3) CI group: Hand irrigation with $1 \mathrm{ml}$ of distilled water was performed using a 27 gauge conventional flat needle (Nipro needle and syringe, Nipro, Japan) positioned $2 \mathrm{~mm}$ short of the working length for 20 seconds.

Each irrigation was performed ten times repeatedly. The mean maximum pressure caused by the irrigation was measured using a pressure sensor (AP-12S, Keyence, Japan) connected via a plastic tube to the model. Data were analyzed by one-way ANOVA and Tukey-Kramer test at a significance level of $p=0.05$.

The mean maximum pressure caused by LAI and PUI was significantly lower than that caused by CI $(p<0.05)$, and that caused by PUI was significantly lower compared to LAI $(p<0.05)$. Under the conditions of this preliminary study, the pulsed Er:YAG laser did create irrigation pressure outside the simulated apical foramen. Although it was smaller than that caused by CI, possible irrigant extrusion through the apical foramen should be considered also in LAI.
\end{abstract}

(J. Jpn. Soc. Laser Dent. $25: 70 \sim 74,2014$ Reprint requests to Dr. SATAKE)

干 113-8549 東京都文京区湯島 1-5-45 TEL 03-5803-5494 FAX 03-5803-5494

1-5-45 Yushima, Bunkyo-ku, Tokyo 113-8549, Japan. TEL + 81-3-5803-5494 FAX + 81-3-5803-5494 
Key words = LAI using Er:YAG laser, root canal irrigation, pressure generated outside the apical foramen キーワード＝ Er:YAG レーザーによる LAI，根管洗浄，根尖孔外の圧カ

\section{緒 言}

根管洗浄は歯内療法の成功のための重要なステップの一 つであり，根管を拡大し根尖まで根管洗浄を行うことで根 管の無菌化が図られる。根管洗浄は従来のシリンジを用い た洗浄法 (Conventional Irrigation, 以下「CI」) が基本 的な術式であり, 現在でも臨床において広く用いられてい る。しかし, CIに使用される次亜塩素酸ナトリウム溶液 が根尖孔外へ溢出することにより，根尖周囲組織を化学的 に傷害し, 疼痛や腫脹を惹起することが数多く報告されて いる ${ }^{1-3)}$ 。このため, CI を含む様々な根管洗浄法における 根尖孔外への洗浄液の溢出量の測定や, 根尖孔外へ加わる 圧力の測定等が行われ, 洗浄液の根尖孔外への溢出につい て検討がなされてきた。我々の過去の研究においても, CIによって根尖孔外に生じる圧力を測定し, 洗浄針や手 技による洗浄液の根尖孔外への溢出挙動について報告し た ${ }^{4)}$ 。また, 根管洗浄の安全性と有効性の向上を目的とし て, 数多くの根管洗浄方法が行われており, 洗浄液を満た した根管内に超音波ファイルを用いてキャビテーションを 発生させ, 洗浄効果を高める超音波洗浄 (passive ultrasonic irrigation, 以下「PUI」) や, 歯科用レーザーを用 いた根管洗浄 (laser-activated irrigation, 以下「LAI」) の有効性が近年報告されている ${ }^{5-9)}$ 。LAIにおいては Blanken と Verdaasdonによって, 洗浄液中で Er,Cr:YSGG レーザー照射した際のキャビテーション現象が示され, 高

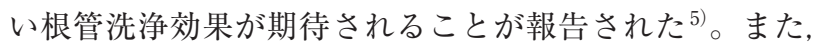

LAI はキャビテーションの他に根管内に高速の水流, 衝 撃波を発生させるともいわれており, これらの現象によっ て Er,Cr:YSGG レーザーあるいは Er:YAG レーザーを用い た LAI では, PUIやCIよりも根管内の根尖部削片の除去 効率が同程度 ${ }^{6)}$ あるいは有意に高かったと報告されてい る7)。また,チップ側方に照射できる根管照射用円錐型 チップを用いたLAIによるキャビテーション挙動につい ても報告されている8)。他方, LAIにおいても根尖孔外へ の洗浄液の溢出が生じたという報告もあり ${ }^{9)}$, LAIによる 根管洗浄時には CI と同様に根尖孔外に圧力が生じる可能 性が考えられる。しかしながら, LAIによって根尖孔外 に生じる圧力を測定した報告はほとんどない。そこで，本 研究では LAI によって根尖孔外に生じる圧力を検討する ことを目的とした。

\section{材料および方法}

\section{I . 模擬根管模型}

プラスチックピペットチップ（\#204 $10 \mu \mathrm{l}$ ショートタイ プ, 先端径 $0.40 \mathrm{~mm}, 0.06$ テーパー, 深江化成, 兵庫) を 調整し, $20 \mathrm{~mm}$ の長さの模擬根管模型として用いた。使 用する実験機器の保全のために, 次亜塩素酸ナトリウム水 溶液の代わりに蒸留水を模擬根管模型内に満たした。

\section{II . 実験群}

模擬根管模型に対して, 以下の 3 群の根管洗浄法を設定 して実験を行った（図 1)。
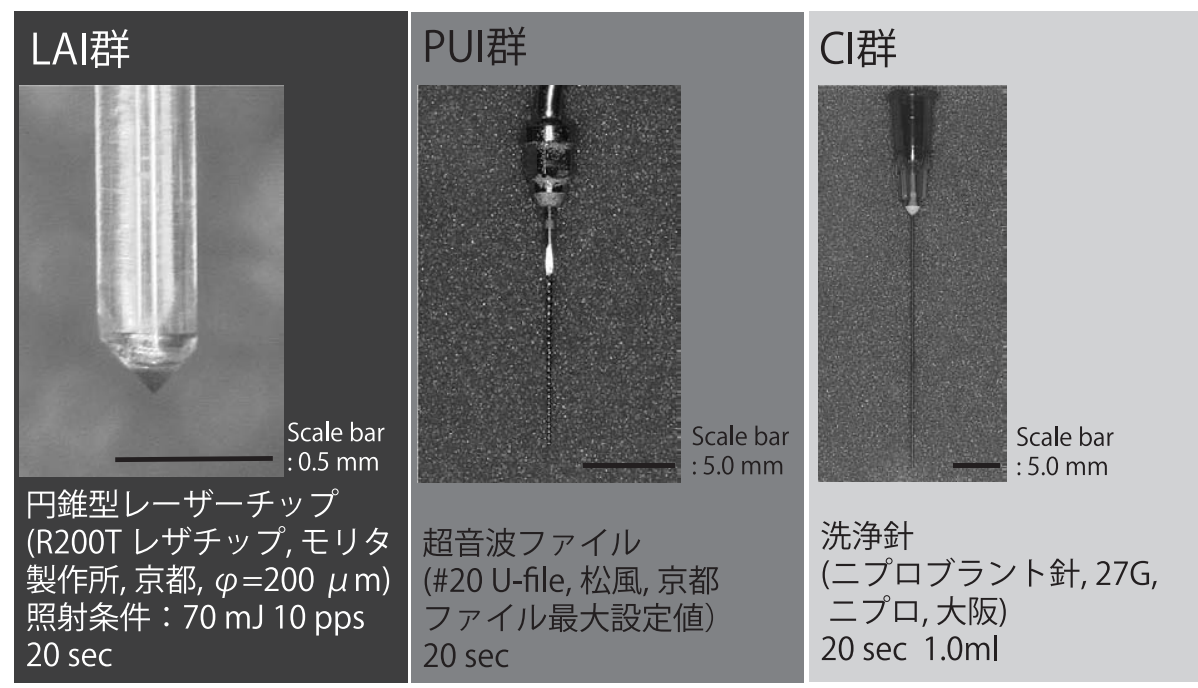

図 1 実験群および使用した装置・器具 


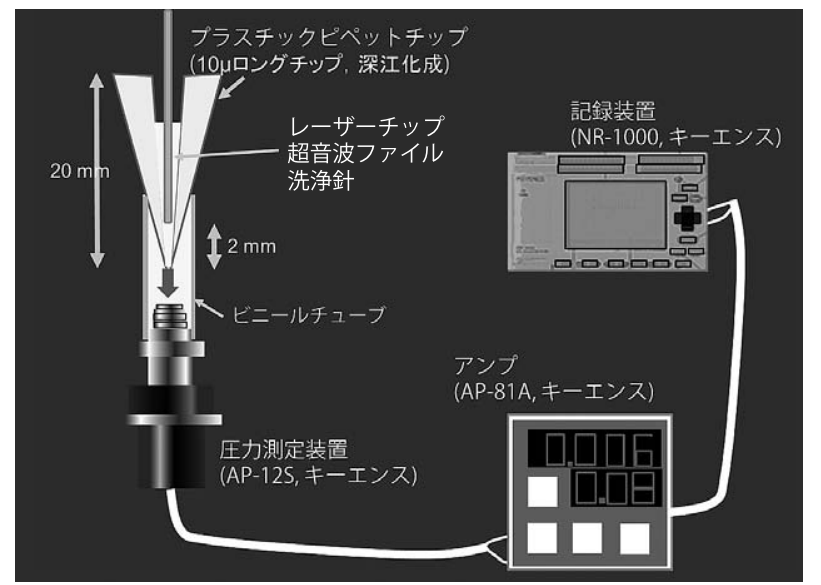

図 2 圧力測定実験装置の模式図

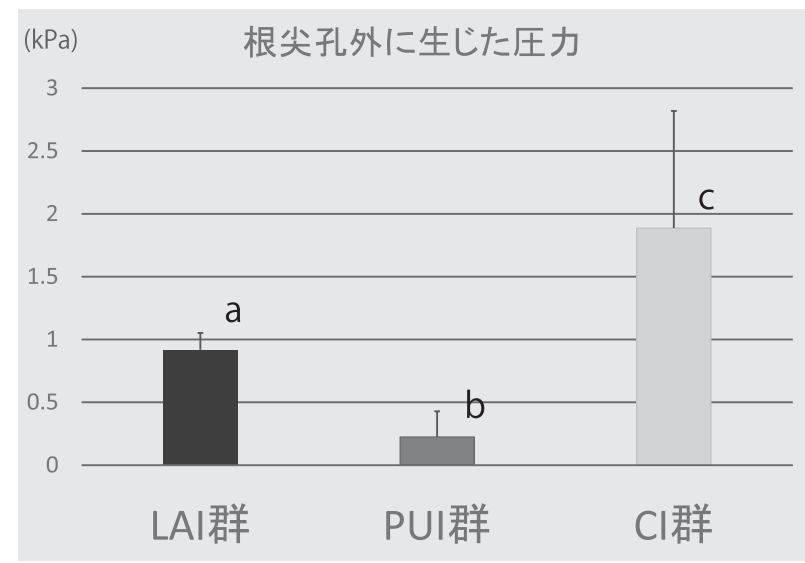

異なる肩文字（アルファベット）は群間に統計学的有意差が存在することを示す (Tukey-Kramer test, $\mathrm{p}<0.05$ )

図 3 根尖孔外に生じた圧力の比較

\section{LAI 群}

LAI 群に打ける Er:YAG レーザー照射には，アーウィ ンアドヴェール（モリ夕製作所，京都）を用いた。本装置 の仕様は, 波長 $2.94 \mu \mathrm{m}$, パルス波発振, 出力エネルギー $30 \sim 350 \mathrm{~mJ} / \mathrm{pulse}$, 繰り返しパルス数 $1 ， 3.3 ， 5,10,20$, 25 pps の各設定が可能であり, レーザーをファイバー伝 送し，コンタクトチップを装着して照射する方式になって いる。本実験に使用したレーザー照射用コンタクトチップ

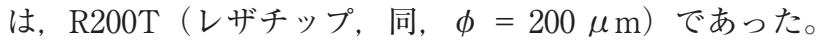
照射出力は, 過去の報告8) を参照し, 同チップの最大設 定值であった $70 \mathrm{~mJ} 10 \mathrm{pps}$ の条件とした。照射位置は, 模擬根管模型の底部から $2 \mathrm{~mm}$ 手前にチップの先端を設置 し, 模擬根管模型内の蒸留水中にて 20 秒間照射を行った。 実験中はチップを同一位置に保持した。

\section{PUI 群}

超音波装置としてピエゾンマスター400（EMS, Switzerland）を用いた。本装置は, 高周波最大出力 $8 \mathrm{~W}$, 周

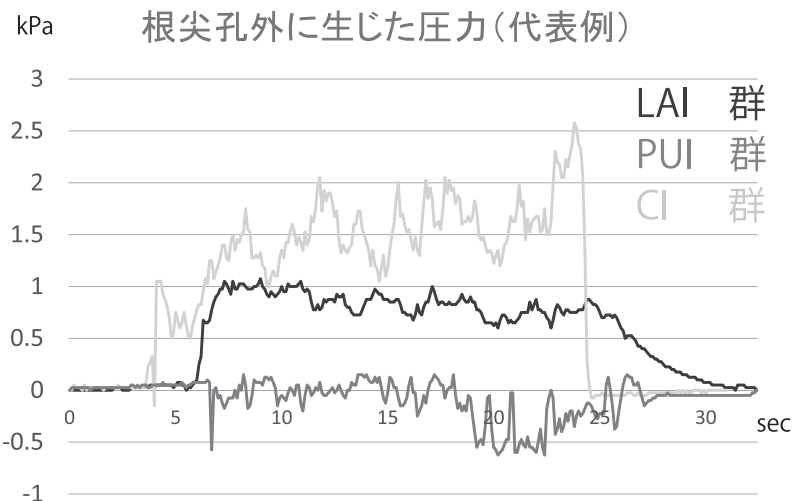

図 4 根尖孔外に生じた圧力の代表例

波数 $24 \sim 32 \mathrm{kHz}$ となっている。超音波ファイルには \#20 のU-ファイル（松風，京都）を用い，同超音波ファイル の最大設定值にて模擬根管模型の底部から $2 \mathrm{~mm}$ 手前に チップの先端を設置し, 模擬根管模型内の蒸留水中にて 20 秒間作用させ，洗浄を行った。

3. CI 群

CI 群では, 広く臨床で用いられている $27 \mathrm{G}(0.40 \mathrm{~mm})$ の洗浄針掞よびシリンジ（ニプロブラント針，ニプロ，大 阪）を用い, 蒸留水 $1 \mathrm{ml}$ で洗浄を行った。その際には, 模擬根管模型の底部から $2 \mathrm{~mm}$ 手前に洗浄針の先端を設置 し，手指により洗浄液を 20 秒間抽送した。

\section{III. 根尖孔外の圧力測定}

根尖孔外に生じた圧力は, 模擬根管模型および蒸留水を 満たしたビニールチューブを介して圧力計測装置（AP$12 \mathrm{~S}$ ，キーエンス，大阪）をアンプ(AP-81A，同）およ び記録装置（NR-1000，同）に接続し（図 2)，各群それぞ れ 10 回ずつ計測し．最大圧力の平均值を測定した（図 2)。

\section{IV. 統計学的解析}

実験結果の統計学的解析には，一元配置分散分析および Tukey-Kramer 法を用いた。有意水準はいずれも $5 \%$ とし た。

\section{結 果}

LAI, PUI およびCI の各群において, 根尖孔外に生じ た圧力の平均最大值はそれぞれ $0.918 \pm 0.134 \mathrm{kPa} ， 0.225 \pm$ $0.203 \mathrm{kPa}, 1.887 \pm 0.931 \mathrm{kPa}$ であった（図 3)。LAI 群お よび PUI 群において根尖孔外に生じた圧力の平均最大值 は，CI 群において生じた圧力の平均最大值よりも有意に 小さかった $(p<0.05)$ 。また, PUI 群は多くの計測で陰 圧あるいは陰圧を中心とした圧の上下変化挙動を示し, LAI 群に比較して有意に小さな圧力を示した $(p<0.05)$ （図 4）なお， LAI および CI 群の平均值は根尖部歯周組織 
の組織圧の水準の一つである中心静脈圧 $5.88 \mathrm{mmHg}=$ $0.79 \mathrm{kPa}$ ) の值を超えていた。

\section{考察}

LAI は根管内にキャビテーション, 高速の水流, 衝撃 波を発生させるとされているが, 本実験条件下では LAI によって根尖孔外に生じた圧力変化は, 従来法である CI よりも小さい結果となった。他方, 用いたレーザー装置, 照射条件が本研究とは異なるものの, George らの報告で は, LAI 群と CI 群間に洗浄液の根尖孔外の溢出量に有

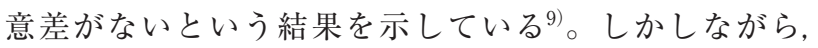
George らの研究方法は抜去歯を水平に固定し, 色素溶液 をLAIにて作用させ, 方眼紙に溢出した色素溶液をプ ロットするという計測方法（面積評価）であったため, CI 群の溢出量の測定は困難であったことが考えられる。 すなわち, 溢出溶液が飛散する挙動を示す LAI と異なり, CI では溢出溶液が垂れて, 根尖孔直下付近に一箇所に溜 まる挙動を示した。そのため面積の評価が実際の溢出量と は異なり, CI 群での計測が過少になっていたことが推察 される。

CI による洗浄液の根尖孔外への溢出についての報告は 数多くなされている10-16)。その測定方法としては, 染色し たゼラチンが次亜塩素酸ナトリウム溶液で漂白された面積 を計測する方法 ${ }^{10,11)}$, 溢出した洗浄液をピペットチップで 吸引して体積を測定する方法 ${ }^{12)}$, 溢出した洗浄液の濃度 を測定する方法 ${ }^{13)}$, 水溶液中に流出した染色液の面積を 撮影して計測する方法 ${ }^{14)}$, あるいは溢出した洗浄液の重 さを測定する方法 ${ }^{15,16)}$ 等が用いられてきた。しかしなが ら, それぞれの方法における測定には限界があると考えら れる。すなわち, 多くの測定方法は面積を測定する 2 次元 評価であること, また根尖孔外の媒体が水溶液あるいはゼ ラチン等である場合, 時間の経過とともに, 根管内に残留 した洗浄液の浸透が起こりうること等が考えられる。ま た, 体積の計測においても時間の経過とともに溢出した洗 浄液の蒸発等による計測誤差が生じることが問題点として 挙げられる。

根尖孔外に生じる圧力を測定する方法は, そのような誤 差がなく, 溢出する勢いの挙動等も計測できる。その反 面, 洗浄液の溢出量自体を測定していないところに問題点 がある。またプラスチック製模擬根管模型は，標準的な根 管形成後の形状を想定したものを用いたが、洗浄液の溢出 挙動が抜去歯の根管とは異なるという報告もある ${ }^{17)} 。 今$ 後, 根尖孔外への洗浄液の溢出に関して, 様々な実験手法 を組み合わせて総合的に勘案する必要があると考えられ る。

実際の臨床では根尖部歯周組織の組織圧が存在し, その 值はヒト中心静脈圧 $(5.88 \mathrm{mmHg}=0.79 \mathrm{kPa})$ に近似する
と報告されている ${ }^{18,19)}$ 。根尖部歯周組織の組織圧は, 根管 洗浄時の圧力に抗すると考えられるが, 本実験の設定条件 下では CI 群, LAI 群において上記の值を超えている例が 認められた。

なお, 本研究では LAI 群の出力がレーザーチップの推 奨出力（30 mJ 10 pps）を超えており，またチップ先端の 位置は根尖付近に設定した。したがって, 出力や設定位置 を変動させた際の LAI における根尖孔外への圧力につい ても測定を行い，最適な照射条件を検討する必要がある。 PUI 群では上記の中心静脈圧值を超えた例は認められず, 根尖孔外の圧力は陰圧あるいは陰圧を中心とした圧の上下 変化挙動を示していた。また, 本研究での PUI 群と CI 群 の結果は Tasdemira らによる報告と同様であった ${ }^{12)}$ 。

キャビテーション発生に関し, PUI では主に超音波振動 によってキャビテーションが生じるのに対して, LAI で はチップ周囲の水の微小爆発によってキャビテーションが 生じると考えられる。チップ周囲部位においては, キャビ テーションによる減圧により LAI, PUI ともに陰圧が生 じると考えられるが, LAIでは微小爆発およびパルス照 射によってチップ前方へ向かう水流が生じ, 根尖孔外に洗 浄液を溢出させ，根尖孔外に陽圧を生じさせたものと考え られる。

本研究で用いた根管照射用レーザーチップは，チップ側 方に $80 \%$ ，前方に $20 \%$ のエネルギーを分配するために, 先端が平坦なチップと比べてチップ前方の圧力は小さい結 果となったものと考えられる。今後, 平坦なチップと比較 した圧力挙動変化についても今後検討する必要がある。

本実験におけるCI 群の洗浄液流量は約 $3 \mathrm{ml} / \mathrm{min}$ であっ た。福元らは, 同僚教室員を対象に根管洗浄液の流量を測 定し, 根管洗浄に扔ける平均流量は $3.46 \mathrm{ml} / \mathrm{min}$ であったと 報告している ${ }^{17)}$ 。また, Park らは $4 \mathrm{ml} / \mathrm{min}$ 以上の流量で は洗浄効率に有意差がなかったという結果を示している ${ }^{20)}$ すなわち, 本実験で計測された流量は臨床的な值であった と考えられる。

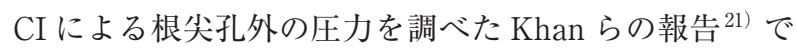
は, $2 \sim 3 \mathrm{ml} / \mathrm{min}$ の流量で洗浄した場合, 根尖孔外の圧 力は $1.89 \pm 0.13 \mathrm{kPa}-3.61 \pm 0.27 \mathrm{kPa} （ 14.15 \pm 0.99-27.1 \pm$ $2.02 \mathrm{mmHg}$ ) であり ${ }^{21)}$, 本研究と同様の結果であった。ま た, $1 \mathrm{ml} / \mathrm{min}$ を超える流量の場合にはヒト中心静脈圧 $(5.88 \mathrm{mmHg}=0.79 \mathrm{kPa})$ を超える圧力が発生したことも 報告している ${ }^{21)}$ 。George らは, in vitro 研究で side-vented 洗浄針を根尖から $10 \mathrm{~mm}$ 離した位置で洗浄した CI 群を 除き, CI および LAI の全ての群で根尖からの洗浄液の溢 出を認めたと報告している9 による臨床研究では, 歯髄壞死症例に対して造影性を付与 した洗浄液を用いて従来法で根管洗浄を行った結果, 洗浄 液が根尖歯周組織へ溢出していたと報告している22)。臨床 
的にどの程度の溢出量で事故に到るか不明であるものの, 洗浄液の溢出は可及的に少なくすることが望ましいといえ よう。今後，レーザーを用いた根管洗浄の臨床応用に際し て, 抜去歯歯根等を用いて, 照射出力, パルスおよびチッ プの設置距離等の照射条件の詳細な設定, 根管側枝の洗浄 効果の有効性の検討等, さらに多角的に明らかにしていく 必要がある。

\section{結 論}

本実験条件下において, Er:YAG レーザーを用いた根管 洗浄法 (LAI) は, 従来の根管洗浄法 (CI) よりも根尖孔 外に生じる圧力が小さかった。しかしながら，LAIにお いても根尖孔外へ洗浄液が溢出する可能性があり, その臨 床応用については更なる検討が必要である。

\section{謝辞}

本研究の一部は, 科学研究費 (平成 $25 \sim 27$ 年度) 若手研究 (B)「分子レベルでの微小破折発生機構の解明と新しい破折制御 概念に基づく歯科治療法の確立」（課題番号：25870195）による 助成を受けて行われた。

\section{参考文献}

1) Sermeño R, Silva L, Herrera H, et al: Tissue damage after sodium hypochlorite extrusion during root canal treatment. Oral Surg Oral Med Oral Pathol Oral Radiol Endod, 108 : e46-e49, 2009.

2) Serper A, Ozbek M, Calt S: Accidental Sodium Hypochlorite-Induced Skin Injury During Endodontic Treatment. J Endod, $30:$ 180-181, 2004.

3) Witton R, Henthorn K, Ethunandan M, et al: Neurological complications following extrusion of sodium hypochlorite solution during root canal treatment. Int Endod J, 38 : 843848, 2005.

4) 小林千尋, 福元康恵, 吉岡隆知, 他 : 根管洗浄時に根尖孔外 に生じる圧力. 日歯内誌, $29 ： 164-169,2008$.

5) Blanken JW, Verdaasdonk RM: Cavitation as a working mechanism of the Er,Cr:YSGG Laser in endodontics: a visualization study. J Oral Laser Appl, 7 : 97-106, 2007.

6) De Moor RJ, Meire M, Goharkhay K, et al: Efficacy of ultrasonic versus laser-Activated irrigation to remove artificially placed dentin debris plugs. J Endod, 36 : 1580-1583, 2010.

7) De Groot SD, Verhaagen B, Versluis M, et al: Laser-activat- ed irrigation within root canals: cleaning efficacy and flow visualization. Int Endod J, 42 : 1077-1083, 2009.

8) Matsumoto H, Yoshimine Y, Akamine A: Visualization of irrigant flow and cavitation induced by Er:YAG laser within a root canal model. J Endod, 37 : 839-843, 2011.

9) George R, Walsh LJ: Apical extrusion of root canal irrigants when using Er:YAG and Er,Cr:YSGG lasers with optical fibers: an in vitro dye study. J Endod, $34: 706-708,2008$.

10) Fukumoto Y, Kikuchi I, Yoshioka T, et al: An ex vivo evaluation of a new root canal irrigation technique with intracanal aspiration. Int Endod J, 39: 93-99, 2006.

11) Mitchell RP, Baumgartner JC, Sedgley CM: Apical extrusion of sodium hypochlorite using different root canal irrigation systems. J Endod, 37 : 1677-1681, 2011.

12) Tasdemira T, Er K, Celik D, et al: Effect of passive ultrasonic irrigation on apical extrusion of irrigating solution. Eur J Dent, 2 : 198-203, 2008.

13) Psimma Z, Boutsioukis C, Kastrinakis E, et al: Effect of needle insertion depth and root canal curvatureon irrigant extrusion ex vivo. J Endod, 39 : 521-524, 2013.

14) Camoes ICG, Salles MR, Fernando MVM, et al: Relationship between the size of patency file and apical extrusion of sodium hypochlorite. Indian J Dent Res, 20 : 426-430, 2009.

15) Yeter KY, Evcil MS, Ayranci LB, et al: Weight of apically extruded debris following use of two canal instrumentation techniques and two designs of irrigation needles. Int Endod J, $46:$ 795-799, 2013.

16) Altundasar E, Nagas E, Uyanik O, et al: Debris and irrigant extrusion potential of 2 rotary systems and irrigation needles. Oral Surg Oral Med Oral Pathol Oral Radiol Endod, 112 : e31-e35, 2011.

17）福元康恵, 吉岡隆知, 須田英明 : 根管内吸引を用いた根管洗 浄法一1. 洗浄液の根尖孔外への溢出について一. 日歯保学雑 誌, $47: 37-42,2004$.

18) Baumann UA, Marquis C, Stoupis C, et al: Estimation of central venous pressure by ultrasound. Resuscitation, 64 : 193-199, 2005.

19) Lyons RH, Kennedy JH, Burwell CS: Measurement of venous pressure by direct Method. Am Heart J, 160 : 675-693, 1938.

20) Park E, Shen Y, Khakpour M, et al: Apical pressure and extent of irrigant flow beyond the needle tip during positivepressure irrigation in an in vitro root canal model. J Endod, $39: 511-515,2013$.

21) Khan S, Niu LN, Eid AA, et al: Periapical pressures developed by nonbinding irrigation needles at various irrigation delivery rates. J Endod, $39:$ 529-533, 2013.

22) Salzgeber RM, Brilliant JD: An in vivo evaluation of the penetration of an irrigating solution in root canals. J Endod, $3: 394-398,1977$. 